A vita összegzéseként megfogalmazódott, hogy az MTA RTB - független szakértő-testületként - kész részt venni az elkészülő koncepció véleményezésében.

Második napirendi pontként - az elözetesen megküldött kutatási koncepcióvázlat alapján - megvitatásra került „,A magyar válság földrajza” c. tervezet, amelyet ENYEDI GYƠRGY terjesztett elö.

Az elốterjesztés vitájában a bizottság aktuális, érđemi feladatnak minősítette a szintézist felvállaló kutatási tervezetet. Annak egyes részkérdéseihez, illetve ezek egy máshoz való tartalmi és logikai viszonyának problémájához, egyes témakörökkel való kiegészítéséhez, az adott közelítés jellemzöen ,ágazati" logikájához kapcsoló đó kérdések és hozzászólások mellett elsôsorban azt firtatták a hozzászólók, hogy vajon adottak-e a feltételek (a szellemi, tudományos muníció) ahhoz, hogy a témakört - a javaslat szerint - viszonylag rövid idő, egy-másfél év alatt színvonalasan tárgyalni lehessen. A bizottság támogatásáról biztosította az előterjesztőt a munka szervezeti, financiális feltételei megteremtésének elindításában. A viszonylag rövid idôn belül elkészítendő résztanulmányok, illetve ezek szintézise birtokában - $\mathrm{s}$ nem e módszerrel szembeállítva - lehet indokolt annak végiggondolása is, hogy az adott témakörben esetleg hosszabb távú, új kutatási irányokat, té mákat is felölelő munka inđuljon. A tematika szerinti munka szervezését, koordinálását az MTA Regionális Kutatások Központja végzi, a tevékenységet a bizot tság figyelemmel kíséri.

NEMES NAGY JÓZSEF

\title{
AZ IPAR KUTATASPOLITIKÁJA ÉS A REGIONÁLIS SZELLEMI CENTRUMOK FEJLESZTÉSÉNEK ÖSSZEFÜGGÉSEI
}

\author{
(Beszámoló az Ipari Minisztérium munkabizottságának \\ 1988. november 11-i üléséról)
}

Szellemi eröforrásaink területi megoszlása szélsôségesen differenciálódott. Míg az ipari munkaerố közel 80\%-a, addig a kutatással-fejlesztéssel foglalkozóknak csak alig 30\%-a dolgozik vidéken. A területi különbségek már létrejöttek a II. világháború előtti Magyarországon is, az azóta eltelt évtizedekben a Budapest-vidék polarizálódás azonban tovább erôsödött.

Az Ipari Minisztérium e téma kutatására munkabizottságot szervezett tudományos kutatókból, politikai munkatársakból, gazđasági szakemberekből. A munkabizottság elnöke Enyedi György akadémikus, titkára Horváth Ảrpád (IPM), koordinátora Szentgyörgyi Zsuzsa (IPM).

A munkabizottság feladatai közé tartozik, hogy megfogalmazza e kutatás tudományos kérđéseit; a korábbi kutatások, információk alapján helyzetképet dolgozzon ki; az ipari fejlesztési politika számára szakvéleményeket készítsen; és körvonalazza a problémakör komplex kutatásainak feladatait. 